\title{
ANALISIS PENGARUH INFLASI, SUKU BUNGA BI, NILAI TUKAR RUPIAH TERHADAP PROFITABILITAS (STUDI KASUS PADA BANK YANG TERDAFTAR DI BEI PERIODE 2011-2015)
}

\author{
Analysis of Effect of Inflation, BI Rate, and Exchange Rate on Bank Profitability \\ (Period 2011-2015) \\ Diska Sasmita $^{1}$, Sri Andriani ${ }^{1}$, Abdul Hadi Ilman ${ }^{1}$ \\ 1 Program Studi Manajemen, Fakultas Ekonomi dan Bisnis Universitas Teknologi Sumbawa \\ *) e- mail: Diskasasmita27@gmail.com
}

\begin{abstract}
ABSTRAK
Penelitian ini bertujuan untuk menganalisis pengaruh inflasi, suku bunga BI dan nilai tukar rupiah terhadap profitabilitas bank yang terdafar di BEI 2011-2015. Metode analisis yang digunakan yaitu metode kuantitatif deskriftif. Teknik analisis deta mengunakan data panel dengan model random effect. Data yang di gunakan yaitu data sekunder berupa rasio keuangan tahunan dari tahun 2011-2015. Pengumpulan data di ambil dengan cara dokumentasi yang bersumber dari laporan publikasi bank. Pengambilan sampel dilakukan secara purposive sampling dengan jumlah 39 bank yang terdaftar di BEI. Hasil penelitian menunjukkan bahwa inflasi berpengaruh positif dan tidak signifikan terhadap ROA, suku bunga berpengaruh negatif dan tidak signifikan terhadap ROA dan nilai tukar berpengaruh negatif dan signifikan terhadap ROA. Secara bersama-sama inflasi, suku bunga dan nilai tukar memiliki pengaruh signifikan terhadap ROA bank umum yang terdaftar di BEI tahun 2011-2015.
\end{abstract}

Kata Kunci : inflasi, suku bunga, nilai tukar dan ROA.

\section{Pendahuluan}

Perkembangan sistem keuangan tidak terlepas dari peran perbankan yang secara mutlak menjadi bagian dari pelaksanaan stabilitas sistem keuangan. Peran penting perbankan bagi perekonomian yaitu meningkatkan kesejahtraan masyarakat (Anjarwati, 2016:24) dan menghimpun dana dari masyarakat dalam berbagai bentuk simpanan (Utomo, 2015:01), serta memberikan fasilitas kredit (Marcia Stigum 1983:20 dalam Suhardi, 2013:75). Sehingga perbankan perlu bertahan dalam melaksanakan kegiatan operasionalnya, tujuan utama operasional sutu bank ialah untuk meningkatkan profit. Salah satu hal yang dapat dilakukan adalah meningkatkan nilai bank sendiri untuk menarik nasabah dan investor yang pada akhirnya akan meningkatkan profirabilitas (Lesmaya,2013:01).

Profitabilitas adalah kemampuan bank untuk memperoleh laba secara efektif dan efisiens, profitabilitas perbankan di ukur melalui beberapa rasio keuangan di antaranya profit margin,retun on asset,return on equity. Diantara rasio keuangan tersebut penulis memilihan ROA, karena ROA merupakan rasio yang mengukur laba bersih yang di dapatkan oleh suatu bank, jika dibandingkan dengan total asset yang dimiliki oleh perusahaan, dengan demikian ROA mengambarkan perolehan laba bersih yang di hasilkan oleh setiap asset bank. Sehingga ROA lebih efektif untuk menghitung kemampuan manajemen bank dalam memperoleh laba secara keseluruhan. Tingkat profitabilitas dengan pendekatan ROA bertujuan untuk mengukur kemampuan

manajemen bank dalam mengelolah aktiva yang di kuasainya untuk mendapatkan pendapatan (Rangga,2013) dalam (Lesmaya, 2013:01).

Tinggi rendahnya ROA di ukur oleh faktor internal dan faktor eksternal. Faktor internal merupakan faktor mikro bank yang menentukan profitabilitas. Faktor eksternal merupakan faktor makro yang berada di luar perusahaan yang mempunyai pengaruh terhadap kenaikan ataupun penurunan kinerja perusahaan baik secara langsung maupun tidak langsung, dan variabel yang tidak memiliki hubungan langsung dengan manajemen bank, akan tetapi faktor tersebut secara tidak langsung memberi efek bagi perekonomian dan hukum yang dimana akan berdampak pada kinerja suatu lembaga keuangan (Mariani, 2014:02). Faktor eksternal yang perlu diperhatikan adalah inflasi, suku bunga, nilai tukar dan siklus output serta variabel-variabel yang merepresentasikan karakteristik pasar (Mariani, 2014:02). Inflasi merupakan meningkatnya hargaharga secara umum dan terus menerus (www.bi.go.id), BI Rate adalah suku bunga kebijakan yang mencerminkan sikap kebijakan moneter yang di tetapkan oleh bank indonesia dan diumumkan kepada publik (Putong,2015). nilai tukar adalah suatu nilai yang menunjukkan jumlah mata uang dalam negeri yang diperlukan untuk mendapat satu unit mata uang asing (Sukirno, 2002).

Berikut ini data fluktuasi ROA pada perusahaan perbankan yang terdaftar di BEI tahun 2011-2015 sebagai berikut: 


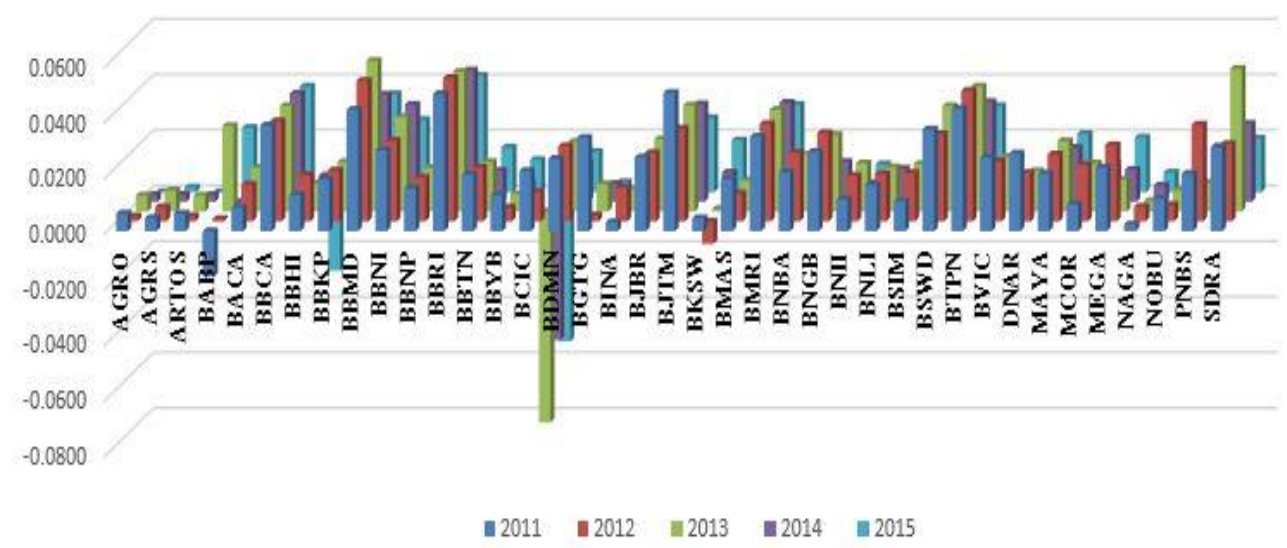

Grafik 1.1 Data Perubahan Tingkat ROA 2011-2015

Pada grafik di atas menunjukkan perubahan ROA yang terdaftar diBEI selama periode 2011-2015. Terlihat pada grafik di atas bahwa ROA setiap tahunnya mengalami fluktuasi. Grafik di atas menujukkan tingkat ROA tertinggi terdapat pada bank Mestika Dharma (BBMD) di tahun 2013, sebesar $5,42 \%$. Sedangkan ROA yang terendah terdapat pada bank Mutiara Tbk (BCIC), pada tahun 2013 sejumlah -7,58\%. Dengan melihat pentingnya perbankan untuk mendapatkan profitabilitas yang tinggi, maka penelitian ini bertujuan untuk mencari pengaruh faktor eksternal yaitu faktor inflasi, suku bunga dan nilai tukar terhadap ROA.

Berdasarkan penejelasan di atas, maka dapat di rumuskan tujuan penelitian sebagai berikut :

1. Untuk mengetahui pengaruh tingkat inflasi terhadap profitabilitas Bank yang terdaftar di BEI.

2. Untuk mengetahui pengaruh tingkat suku bunga terhadap profitabilitas Bank yang terdaftar di BEI.

3. Untuk mengetahui pengaruh tingkat nilai tukar terhadap profitabilitas Bank yang terdaftar di BEI.

4. Untukmengetahuipengaruhinflasi, suku bunga dan nilai tukar terhadap profitabilitas bank yang terdaftardi BEI.

\section{Hipotesis}

Hipotesis di rumuskan atas dasar kerangka pikir yang merupakan jawaban sementara dari masalah yang di rumuskan. Di mana jawaban dari rumusan masalah di dasarkan pada teori dan penelitian empiris sebelumnya, maka hipotesis yang dapat di ambil mengenail pengaruh inflasi, suku bunga dan nilai tukar terhadap ROA adalah sebagai berikut :

\section{Pengaruh Inflasi Terhadap ROA}

Berdasarkan penelitian yang dilakukan Perry dalam Sastrosuwito dan Suzuki (2011) menyatakan bahwa dampak dari inflasi pada profitabilitas tergantung pada apakah inflasi diantisipasi atau tak terduga. Dimana inflasi sepenuhnya diantisipasi, maka semua suku bunga akan naik untuk menyertakan inflasi sehingga peningkatan pendapatan lebih cepat dari biaya, dengan dampak positif pada profitabilitas, dengan di antisipasinya inflasi. Inflasi merupakan proses dari suatu peristiwa, bukan tinggi rendahnya tingkat harga artinya tingkat harga yang dianggap tinggi belum tentu menunjukkan inflasi. Inflasi dianggap terjadi jika proses kenaikan harga berlangsung secara terus menerus dan saling mempengaruhi. Inflasi yang tinggi akan menyebabkan berkurangnya asset, karena dengan inflasi yang tinggi akan menyebabkan daya beli masyarakat, sehingga akan mengurangi asset yang di miliki perusahaan. Inflasi yang meningkat akan mengurangi kekuatan daya beli rupiah yang telah di investasikan. Oleh karena itu, resiko inflasi juga biasa di sebut sebagai resiko daya beli. Jika inflasi mengalami peningkatan, investor biasanya menuntut tambahan premium inflasi untuk mengkompensasi penurunan daya beli yang di alaminya (Tandelilin,2013:103).

Secara empires banyak penelitian dengan latar belakang sampel yang berbeda beda telah membuktikan bahwa inflasi berpengaruh positif terhadap ROA seperti yang di ungkapkan oleh Ayu (2013) yang menyatakan bahwa ternyata terdapat pengaruh secara persial maupun simultan antara variabel inflasi terhadap ROA. Jadi berdasarkan teori yang di paparkan dan penelitian sebelumnya bahwa kebanyakan peneliti mengatakan bahwa inflasi berpengaruh positif dan signifikan terhadap ROA.

\section{Pengaruh Suku Bunga BI Terhadap ROA}

Dalam teori ekonomi makro, salah satu faktor yang mempengaruhi profitabilitas bank adalah suku bunga. Kenaikan tingkat BI rate mendorong terjadinya kenaikan tingkat suku bunga kredit yang kemudian menyebabkan biaya bunga pinjaman meningkat, sehingga pendapatan yang di terimah oleh bank dari bunga pinjaman kredit akan meningkat. Apabila pendapatan bunga naik maka laba yang di terima oleh bank juga akan meningkat. Dengan kata lain, kenaikan suku bunga BI akan meningkatkan ROA (akan tetapi dengan asumsi kenaikan suku bunga BI di ikuti oleh kenaikan suku bunga kredit dan suku bunga deposito sehingga biaya bunga ikut naik dan pendapatan bunga di terima oleh bank akan semakin besar) Dengan demikian dapat dirumuskan bahwa tingkat suku bunga BI berpengaruh positif dan signifikan terhadap ROA (Puspitasari 2009,47).

Selanjutnya dari pernyataan yang di paparkan sebelumnya dan teori yang didukung oleh (Puspita Sari, 2009:47). Hipotesis Suku bunga BI berpengaruh positif dan signifikan terhadap ROA di karenakan banyaknya penelitian yang menyatakan bahwa suku bunga berpengaruh terhadap profitabilitas bank, di mana pada dasarnya naiknya tingkat suku bunga akan meningkatkan hasrat masyarakat untuk menabung, sehingga 
jumlah dana perbankan akan meningkat, di mana saat naik turunnya suku bunga merupakan penentu sedikit ataupun banyak masyarakat yang menghipun dananya di bank. Sehingga apabila naiknya suku bunga akan banyak masyarakat yang menabung di bank. Ini akan membuat dana perbankan akan meningkat seingga akan menaikan profitabilitas bank (Pohan, 2008) dalam (Dwijayanti \& Noumi, 2009:03).

\section{Pengaruh Nilai Tukar Rupiah Terhadap ROA}

Nilai valuta asing atau nilai tukar adalah suatu nilai yang menunjukkan jumlah mata uang dalam negeri yang diperlukan untuk mendapat satu unit mata uang asing (Sukirno, 2002). Dalam suatu perbankan, nilai tukar mempunyai pengaruh terhadap tingkat profitabilitas. Nilai tukar akan menentukan imbal hasil investasi riil. Mata uang yang menurun secara jelas akan mengurangi daya beli dari pendapatan dan keuntungan modal yang didapat dari jenis investasi apapun. Penurunan investasi ini akan mempengaruhi kegiatan operasional bank. Sehingga setiap perubahan nilai tukar valas akan mempengaruhi pendapatan dan profit bank (Sukirno, 2006:38). Penelitian oleh Rosanna (2007) mengatakan bahwa nilai tukar berpengaruh signifikan terhadap profitabilitas bank.

Menurut Arifi dalam Putra (2009:43) Apabila terdepriasi rupiah terhadap dollar maka akan berdampak pada penurunan Profitabilitas bank. Nilai tukar mengalami depresiasi atau kelemahan rupiah terhadap dollar, perusahaan akan mengurangi biaya ekspor, sehingga akan membuat laba perusahaan menurun, dan perusahaan tidak dapat memperoleh kredit dari bank untuk mengembangkan usahanya dan menyebabkan biaya pinjaman atau kewajiban yang harus di bayar menjadi naik dan membuat profitabilitas bank menurun. Berdasarkan teori dan penelitian terdahulu bahwa nilai tukar berpengaruh negatif dan signiifikan.

4. Pengaruh Inflasi, Suku Bunga dan Nilai Tukar BI terhadap ROA

penelitian yang dilakukan oleh Mariani (2014) dan lesmaya (2013), menjelaskan bahwa inflasi, suku bunga BI dan nilai tukar rupiah berpengaruh signifikan terhadap ROA, menjelaskan apabila faktor ekternal mempunyai perubahan yang baik dan pelaku perbankan cenderung untuk meresponnya secara keseluruhan sehingga membuat variabel eksternal mempengaruhi pendapatan dan profit bank di masa yang akan datang dan akan membuat investor untuk menginvestasikan dana yang dimilikinya.

\section{Metode Penelitian}

Metode yang digunakan dalam penelitian ini adalah Metode Kuantitatif diskriptif, metode kuantitatif adalah pendekatan yang menggunakan data yang berbentuk angka pada analisis statistik, penelitian ini merupakan penelitian yang bertujuan untuk mengetahui hubungan antara dua variabel atau lebih (Sugiyono, 2016:7), deskriptif adalah studi yang bertujuan untuk memperoleh deskriptif yang lengkap dan akurat dari suatu situasi (Kuncoro, 2011:3).

Jenis data yang digunakan dalam penelitian ini adalah data sekunder yaitu berupa data panel yang merupakan gabungan silang (cross section) dan data runtun waktu (time series) selama kurun waktu 2011-2015. Jenis data panel yang digunakan dalam penelitian ini yaitu balanced panel, dimana setiap unit cross section memiliki jumlah observasi runtun waktu (time series) yang sama (Suliyanti:299 dalam
Mutmainah, 2013:53). Sumber data yang digunakan dalam penelitian ini berasal dari laporan keuangan bank-bank yang terdaftar di BEI dari tahun 2011-2015.

Populasi yang digunakan dalam penelitian ini adalah 39 perusahaan perbankan yang terdaftar di BEI dengan menyampaikan laporan keuangannya ke BEI dari tahun 20112015. Metode penentuan sempel yang digunakan dalam penelitian ini yaitu metode sampling purposive. Metode sampling purposive merupakan penentuan sampel dengan pengumpulan data-data tertentu yang di anggap sesuai dan terkait dengan penelitian yang di lakukan.

Sampel dalam penelitian ini dipilih dengan menggunakan sampling purposive dengan kriteria. Pertama seluruh bank yang terdaftar di BEI dari tahun 2011-2015. Kedua, perusahaan perbankan yang menerbitkan laporan keuangan secara lengkap dari tahun 2013 2015.Terakhir bank yang menyajikan secara lengkap laporan keuangan dan rasio-rasio yang di butuhkan dalam penelitian ini selama 5 tahun berturutturut.

\section{Meodel Analisis Regresi Data Panel}

Dalam penelitian ini penulis mengunakan model data panel, untuk memgetahui apakah pengaruh inflasi, suku bunga dan nilai tukar terhadap ROA dengan mengunakan regresi linear berganda sebagai berikut :

$Y_{i t}=a+b_{1} X_{1 i t}+b_{2} X_{2 i t}+b_{3} X_{3 i t}+e_{i t}$

Dimana :

$\begin{array}{ll}Y & : \text { ROA } \\ a & : \text { Konstanta } \\ X_{1} & \text { : Inflasi } \\ X_{2} & \text { :Bunga } \\ X_{3} & \text { :Nilai Tukar } \\ b_{(1,2,3)} & : \text { Koefisien masing-masing variable } \\ t & \text { : Waktu } \\ i & \text { : Perusahaan } \\ e & \text { : Error term }\end{array}$

Ada beberapa pendekatan yang di gunakan dalam menguji data panel yaitu:

1. Pooled Least Square (PLS) merupakan pendekatan yang tidak memperhatikan dimensi individu maupun waktu. Dengan diestimasikan bahwa perilaku antara perusahaan sama dalam beberapa kurun waktu.

2. Model Fixed Effects merupakan teknik mengestimasi data panel dengan menggunakan variabel dummy untuk menangkap adanya perbedaan intersep.

3. Model Random Effects merupakan teknik untuk mengatasi ketidakpastian dari model yang digunakan oleh fixed effects, dan didalam teknik ini diambil beberapa sampel dipilih secara acak dan merupakan perwakilan dari populasi.

Untuk menentukan model regesi mana yang baik untuk digunakan maka dilakukan beberapa pengujian yaitu uji chow yang digunakan untuk memilih model antara $P L S$ atau fixes effect, uji hausman di gunakan untuk menentukan metode fixes effect dan random effect dan yang terakhir uji LM Test di lakukan ketika hasil yang didapatkan pada uji chow menunjukkan $P L S$ yang diterima. Dari pengujian yang telah dilakukan metode atau pendekatan yang digunakan yaitu 
random effect yang di harapkan akan mampu mengatasi heteroskedastisitas dan autokorelasi yang akan terjadi.

\section{Tahapan Analisis Data}

menganalisis dan untuk memilih metode estimasi yang tepat diantara ketiga jenis metode yang tepat, diperlukan uji spesifikasi model, uji tersebut ialah:

\section{Uji Chow}

Dilakukan uji chow ini untuk memilih model mana yang terbaik dalam mengestimasi data panel antara PLS dan fixed effect.

\begin{tabular}{ll}
\hline Uji Chow & Keterangan \\
\hline Nilai Profitabilitas F & Prob $>\mathrm{F}=0.0000$ \\
Hasil & Tolak Ho \\
\hline
\end{tabular}

Ho : PLS

Ha : Fixes Effect

\section{Uji Hausman}

Dilakukan uji untuk memilih model mana yang terbaik dalam mengestimasi data panel antara fixed effect dan random effect.

Ho : Random effects model

Ha : Fixed Effects Model

\section{Uji LM}

Dilakukannya uji ini untuk memilih model estimasi antara $P L S$ atau random effect. LM Test di lakukan ketika hasil yang di dapatkan pada uji chow menunjukkan Ho diterima. Hipotesis yang digunakan dalam pengujian ini yaitu :

Ho : PLS

\section{Ha : Random effect Model}

Untuk menjawab hipotesis yag telah dimuat maka dilakukan pengujian sevagai berikut:

1. Uji Simultan (F)

Uji statistik $\mathrm{F}$ menunjukkan apakah semua variabel yang dimasukkan dalam model mempunyai pengaruh secara bersamaan terhadap variabel terikat (Kuncoro, 2011: 106). Jika F-statistik > F-tabel maka variabel independen secara bersamaan berpengaruh secara signifikan terhadap variabel dependen.

\section{Uji Parsial (t)}

Uji versial pada dasarnya digunakan untuk mengetahui pengaruh satu variabel penjelas secara individual dalam menerangkan variasi variabel berikut (Kuncoro, 2011: 105). Jika t-statistik > t-tabel maka variabel bebas mempengaruhi variabel terikat secara signifikan, artinya dengan tingkat signifikansi $\alpha$ secara parsial (individual) variabel bebas berpengaruh secara signifikan terhadap varibel terikat.

3. Uji Koefisiens Determinasi $\left(\mathrm{R}^{2}\right)$

Uji Koefisien Determinasi $\left(\mathrm{R}^{2}\right)$ adalah untuk mengetahui seberapa besar persentase variasi variabel independen mempengaruhi variabel dependen. Nilai $\mathrm{R}^{2}$ terdapat pada kisaran nol sampai satu. Nilai $\mathrm{R}^{2}$ mendekati nol dapat di artikan bahwa variasi variabel independen dalam menjelaskan variasi variabel independen sangat terbatas. Jika $\mathrm{R}^{2}$ mendekati satu berarti variasi variabel dependen memberikan hampir semua informasi yang di butuhkan untuk memprediksi variasi variabel dependen.

\section{Hasil Analisis Data dan Pembahasan}

\section{Penentuan Teknik Estimasi Data Panel}

Untuk mengetahui metode yang tepat untuk penelitian ini maka dilakukan beberapa pengujian yaitu :

\section{Uji Chow}

Uji chow dilakukan untuk memilih mana yang tepat antara PLS dan random effect. Kriteria keputusan:

Ho : PLS

Ha : Fixed Effects Model

Tabel 1.1 Hasil Uji Chow

\section{Uji Hausman}

Digunakan untuk menentukan metode yang tepat antara Fixed Effects Model dan Random effects model. Kriteria penolakan :

\section{Ho : Random effect Model}

H1 : Fixed Effect Model

Tolak Ho jika nilai Prob chi2 < alfa

Tabel 2. Hasil Uji Hausman

\begin{tabular}{ll}
\hline Hausman Test & Keterangan \\
\hline Nilai Profitabilitas chi ${ }^{2}$ & Prob $>$ chi $^{2}>=1.0000$ \\
Hasil & Terima Ho \\
\hline
\end{tabular}

Hasil dari tahapan diatas dapat di simpulkan, dari ketiga model antara PLS, Random effect Model dan Fixed Effect Model. model yag tepat di gunakan dalam penelitian ini yaitu Random effect.

\section{Hasil Uji Hipotesis}

Berikut merupakan hasil estimasi data panel dengan menggunakan model Random effect :

Tabel 3. Hasil Estimasi Data Panel

\begin{tabular}{|c|c|c|c|}
\hline $\begin{array}{l}\text { Prob > chi2 } \\
\text { R-Square }\end{array}$ & & & $\begin{array}{l}=0.0000 \\
=0.0465\end{array}$ \\
\hline Roa & Coef. & Std. Err. & Sig. \\
\hline Inflasi & 0.0606953 & 0.0902852 & 0.501 \\
\hline Suku bunga & -0.113102 & 0.1264873 & 0.371 \\
\hline Nilai tukar & $-1.90 \mathrm{E}-06$ & $7.66 \mathrm{E}-07$ & 0.013 \\
\hline _cons & 0.0424409 & 0.0070364 & 0.000 \\
\hline
\end{tabular}


Estimasi model yang didapatkan dari hasil regresi data panel ditunjukkan oleh tabel 3 , sebagai berikut :

$R O A_{i t}=0,0424409+0,0606953$ inflasi $_{i t}-0,113102$ suku bunga $a_{i t}-1,90 \mathrm{E}-06$ nilai tukar $_{i t}+U_{i t}$

\section{Pengaruh Inflasi Terhadap ROA}

Dari hasil yang didapatkan dari tabel 4.3, nilai koefisien sebesar 0,06066953 dan nilai probabilitas pada variabel inflasi sebesar 0,501. Nilai probabilitas t lebih besar dari tingkat signifikan 0,05 (prob t > 0,05). Jadi secara persial Ho diterima dan Ha ditolak sehingga dapat disimpulkan bahwa inflasi tidak signifikan terhadap ROA pada bank umum yang terdaftar di BEI pada periode 2011-2015. Hal ini mengindikasikan semakin tinggi tingkat inflasi, maka akan semakin baik kinerja bank dalam menghasilkan laba.

Inflasi yang tinggi mencerminkan kenaikan barang-barang yang menjadikan nilai peredaran uang dapat berkurang akibat harga yang meningkat (Maulana, 2015:87) dan dengan inflasi yang tinggi dapat berkurangnya asset. Akibat dari tingginya inflasi akan membuat daya beli masyarakat berkurang, karena hal tersebut akan mengurangi asset yang dimiliki perusahaan. Dari sisi lainnya dengan meningkatnya inflasi akan berkurangnya kekuatan daya beli rupiah yang telah di investasikan. Sehingga resiko inflasi di sebut juga sebagai resiko daya beli. Jika inflasi mengalami peningkatan, investor biasanya menuntut tambahan premium inflasi untuk mengkompensasi penurunan daya beli yang telah alamin (Tandelilin,2013:103). Hasil yang di dapatkan ini sesuai dengen penelitian yang di lakukan oleh Febriani Dwijayanthy dan Prima Naomi (2009) dengan penelitian yang berjudul "Analisis Pengaruh Inflasi, BI Rate, dan Nilai Tukar Mata Uang terhadap Profitabilitas Bank Periode 2003-2007 . Dari hasil penelitian yang didapatkan bahwa inflasi tidak berpengaruh terhadap profitabilitas bank dan BI rate berpengaruh negatif terhadap profitabilitas bank. Sedangkan nilai tukar berpengaruh positif terhadap profitabilitas bank.

Inflasi merupakan proses dari suatu peristiwa, bukan tingginya tingkat harga artinya tingkat harga yang diangap tinggi belum tentu menunjukkan inflasi.. Hal ini akan cendrung mempengaruhi jumlah laba yang diperoleh, dalam penelitian ini menunjukkan bahwa meskipun inflasi mengalami kenaikan, namun ROA yang diperoleh suatu bank tidak mengalami penurunan ataupun kenaikan sehigga hal ini membuat inflasi tidak berpengaruh signifikan.

\section{Suku bunga terhadap profitabilitas (ROA)}

Dari hasil yang didapatkan dari dari tabel 4.3. Nilai koefisien sebesar -0.113102 dan nilai probabilitas pada variabel suku bunga sebesar 0.371. Dapat dilihat bahwa nilai probabilitas t lebih besar dari tingkat signifikan 0,05 (prob t $>0,05$ ). Jadi secara persial Ho diterima dan Ha ditolak, sehingga dapat disimpulkan bahwa suku bunga tidak signifikam dan berpengaruh negatif terhadap ROA bank umum yang terdaftra di BEI.

Penelitian ini didukung oleh penelitian yang di lakukan Wibowo \& Syaichu (2013) bahwa penelitian menunjukkan bahwa suku bunga tidak berpengaruh signifikan terhadap ROA perbankan di Bursa Efek Indonesia. Tidak adanya pengaruh yang signifikan ini mengindikasikan bahwa besar kecilnya BI rate pada periode tahun 2011 - 2015 tidak berdampak besar pada naik turunnya ROA bank yang terdaftar di BEI.

Dalam hal ini dengan meningkatnya jumlah suku bunga maka akan meningkatkan suku bunga kredit yang kemudian akan diikuti oleh suku bunga tabungan. Dalam penelitiannya jumlah kredit dengan meningkat suku bunga akan menyebabkan total pinjaman berkurang disebabkan berkurangnya kemampuan peminjan dana untuk membayar pinjamannya dengan selisih bunga, sehingga jumlah selisih bunga berkurang. Namun dengan seiring meningkatnya suku bunga tabungan atau suku bunga deposito tidak serta merta masyarakat akan menyimpan sejumlah dananya kepada bank. Hal ini diakibatkan adaanya faktor makro lain seperti inflasi yang menyebabkan masyarakat menggunakan sejumlah danannya (Rahman, 2015:84)

Dalam penelitian ini hubungan BI Rate terhadap ROA bank yang terdaftar di BEI tahun 2011-2015, juga mempengaruhi profitabilitas suatu bank. Semakin tinggi suku bunga BI maka akan diikuti naik turunnya suku bunga deposito dan suku bunga kredit. Setiap pergerakan suku bunga yang terjadi di tahun 2011-2015 diikuti kenaikan suku bunga kredit dan suku bunga deposito, dalam hal ini suku bunga kredit tetap mengalami kenaikan akan tetapi suku bunga deposito berada di bawah suku bunga kredit, hal ini membuat selisih antara suku bunga kredit dan suku bunga deposito yang akan menjadi Net Interest Margin (NIM) suatu perusahaan bank yang terdaftar di BEI tahun 2011-2015 mengalami perubahan, sehingga membuat ROA mengalami fluktuasi yang rendah, hal ini yang menyebabkan bahwa dalam penelitian ini ROA bank yang terdaftar di BEI tahun 2011-2015 tidak berpengaruh signifikan.

\section{3. pengaruh Nilai Tukar Terhadap ROA}

Dari hasil yang didapatkan dari tabel 4.3, nilai koefisien sebesar -1.90E-06 dan nilai probabilitas pada variabel nilai tukar sebesar 0,013. Dapat dilihat bahwa nilai probabilitas $t$ statistik lebih kecil dari tingkat signifikan 0,05 (prob t < 0,05). Jadi secara persial Ha diterima dan Ho ditolak, sehingga dapat disimpulkan bahwa secara persial nilai tukar berpengaruh negatif dan signifikan tehadap ROA bank yang terdaftar di BEI.

Dalam penelitian ini membuktikan fluktuasi nilai tukar rupiah terhadap dollar berpengaruh terhadap perubahan ROA dalam suatu perbankan. Penelitian ini menunjukkan nilai tukar rupiah pada dollar mengalami apresiasi hal ini berdampak pada apresiasi profitabilitas bank (ROA), apresiasi nilai tukar rupiah terhadap dollar hanya berdampak signifikan pada perbankan yang mempunyai hubungan secara langsung dengan mata uang asing dan pengaruh yang signifikan ini mengindikasikan bahwa besar kecilnya Kurs pada periode tahun 2011 - 2015 berdampak besar pada naik turunnya ROA bank.

Hasil penelitian ini menunjukkan nilai tukar mengalami depresiasi dari tahun 2011-2015 sehingga menyebabkan kondisi ROA yang tinggi akan menurun sedangkan ketika nilai tukar mengalami apresiasi maka kondisi ROA akan naik, Sehingga dalam penelitian ini nilai tukar rupiah terhadap dollar mengalami depresiasi. Terjadinya depresiasi rupiah terhadap dollar maka akan berdampak pada apresiasi Profitabilitas bank yang terdaftar di BEI tahun 2011-2015 dalam penelitian ini, sehingga semakin tinggi kemampuan perusahaan dalam membayar kewajiban atau hutang perusahaan perbankan. 
sehingga dalam penelitian ini besar kecilnya kurs pada tahun 2011-2015 akan berpengaruh signifikan terhadap ROA. Dengan terjadinya depresiasi nilai tukar terhadap dollar dalam penelitian ini, akan membuat perusahaan mengurangi biaya ekspor, dan membuat laba perusahaan menurun dan perusahaan tidak dapat memperoleh kredit untuk mengembangkan usahanya dan membuat biaya pinjaman yang harus dibayar menjadi naik dan membuat ROA mengalami penurunan sehingga nilai tukar berpengaruh negatif terhadap ROA.

\section{Uji Regresi Simultan}

Berdasarkan analisis hasil regresi data panel yang ditunjukkan pada tabel 3 diatas menunjukkan bahwa nilai , Wald chi2 sebesar 0,0000 dengan tingkat probabilitas lebih kecil dari $0.05(0.0000<0.05)$. Maka pengaruh variabel secara simultan dikatakan signifikan dan Ha dapat diterima. Sehingga dapat disimpulkan bahwa inflasi, suku bunga dan nilai tukar secara bersama-sama berpengaruh secara signifikan terhadap ROA bank umum yang tetrdaftar di BEI dalam periode tahun 20112015. Hal ini menjelaskan bahwa ketika investor melakukan investasi dapat melihat variabel ekternalnya baik atau buruk, karena akan berdampak pada asset bank. Semakin baik faktor ekternal maka profit suatu bank akan meningkat. Hasil penelitian ini sesuai dengan penelitian sebelumnya dilakukan oleh Mariani (2014) dan lesmaya (2013) bahwa secara simultan bahwa inflasi, suku bunga BI dan nilai tukar rupiah berpengaruh signifikan terhadap ROA.

\section{Uji Koefisien R-sq Overall}

Nilai $R^{2}$ sebesar 4,65\% profitabilitas perusahaan perbankan dapat di jelaskan oleh variasi tiga variabel bebasnya secara bersama-sama yaitu inflasi, suku bunga BI dan nilai tukar. Sedangkan sisanya 95,35 dijelaskan oleh variabel lain diluar model atau tidak dimasukkan ke dalam penelitian ini. Variabel-variabel tersebut ialah Loan to Deposit Ratio (LDR),Non Performing Loan, Capital Adequacy Ratio (CAR), Non Performing Loan (NPL).

\section{Kesimpulan}

Berdasarkan pada hasil penelitian dan pembahasan yang telah diuraikan sebelumnya maka disimpulkan sebagai berikut:

1. Hasil empires yang telah dilakukan secara simultan ialah inflasi, suku bunga BI dan nilai tukar rupiah berpengaruh signifikan terhadap ROA pada bank yang terdaftar di BEI. Dapat dilihat dengan nilai profitabilitas sebesar 0,0000 yang berarti di bawah 0,05. D mana Ha diterima dan Ho ditolak.

1. Hasil empires yang telah dilakukan secara persial bahwa variabel inflasi berpengaruh positif dengan nilai koefisien sebesar 0.0606953 dan tidak signifikan secara persial terhadap ROA bank yang terdaftar di BEI, dengan nilai profitabilitas 0.501 yang berarti lebih besar dari 0,05. Maka Ha ditolak dan Ho diterima.

2. Hasil empires yang telah dilakukan secara persial bahwa variabel suku bunga berpengaruh negatif dengan nilai koefisien sebesar -0.133102 dan tidak signifikan secara persial terhadap ROA bank yang terdaftar di BEI, dengan nilai profitabilitas 0.371 yang berarti lebih besar dari 0,05. Maka Ha ditolak dan Ho diterima.

3. Kemudian nilai tukar secara empires berpengaruh negatif dengan nilai koefisien sebesar $-1.90 \mathrm{E}-06$ dan signifikan terhadap ROA bank yang terdaftar di BEI dengan nilai profitabilitas 0,013 yang berarti lebih kecil dari 0,05. Maka Ha diterima dan Ho ditolak.

\section{Saran}

Bagi penelitia ataupun pembaca selanjutnya, diharapkan penelitian ini dapat menjadi referensi dan masukan untuk menambah wawasan. Diharapkan kepada peneliti selanjutnya untuk dapat menambah jumlah variabel dalam penelitiannya agar dapat memberikan informasi yang baru dan lebih banyak lagi.

\section{Daftar Pustaka}

Sugiyono. (2016). Metode Penelitian Kuantitatif, Kualitatif, dan $R \& D$. Bandung: Alfabeta.

Astriani, L. (2013). Analisis pengaruh dana pihak ketiga (DPK), nilai tukar, suku bunga sertifikat bank indonesia (SBI), inflasi dan capital adequacy ratio (CAR) terhadap profitabilitas pada bank umum periode 2007-2011. Manajemen, 08.

Kusumaningtias, D. M. (2012). Pengaruh Inflasi, Suku Bunga , Nilai Tukar valas Dan Jumlah Uang Beredar Terhadap Profitabilitas Pada Perbankan Syariah di Indonesia Periode 2005-2009. 164.

Mariani. (2014). Analisis Pengaruh Perubahan Kurs dan BI Rate Terhadap Profitabilitas Perbankan di BEI Tahun 2004 - 2013. Ilmu Ekonomi , 02.

Maulana, M. R. (2015). Analisis pengaruh inflasi, nilai tukar, capital adequacy ratio, biaya operasional dan terhadap profitabilitas pada perbankan syariah periode 2010-2014. Ilmu Ekonomi , 75.

Rahman, M. N. (2015). Analisis pengaruh dana pihak ketiga, BI Rate, dan kurs rupiah terhadap profitabilitas (ROA) pada bank persero di indonesia pada periode 2008-2014. Manajemen, 14.

Utomo, B. S. (2015). Analisis pengaruh CAR, NPL, PDN, NIM, BOPO, LDR dan suku bunga SBI terhadap ROA. Ekonomi Pembangunan , 16.

Mankiw, N. G. (2008). Pengantar Ekonomi makro. Jakarta: Selemba Empat.

http://www.idx.co.id

http://www.bi.go.id

Abdullah, B. (2006). Menanti kemakmuran negeri (kumpulan Esai tentang pebangunan sosial ekonomi indonesia). Gramedia Pustaka Utama: 337.

Rifka Regar, W. A. (2016). Analisis Pemberian Kredit Mikro Terhadap Peningkatan Nasabah. Administrasi Bisnis , 02.

Naomi, F. D. (2009). Analisis Pengaruh Inflasi, BI Rate, dan Nilai Tukar Mata Uang terhadap Profitabilitas Bank. 89.

Putong, I. (2015). Ekonomi Makro: Pengantar untuk dasardasar Ekonomi Makro. Jakarta: Iskandar Putong. 
Latan, H. (2014) Aplikasi Analisis Data Statistik Untuk Ilmu Sosial Sains dengan STATA. Bandung : ALFABETA,cv.

Mutmainah.(2013). Analisis Return On Asset, Loan To Deposit, dan Non Performing Loan Terhadap Penyaluran Kredit (Studi Kasus Pada Sektor Perbankan yang Terdaftar di BEI).55.

Prof. Dr. Jogiyanto Hartono, M. (2014). Metodologi Penelitian Bisnis. Yogyakarta: BPFE.

Prof. Madrajat Kuncoro, P. (2011). Metode Kuantitatif (4ed). Yogyakarta : UPP STIM YKPN.

Ratna Prihantini, S. (2009). Analisis Pengaruh Inflasi, Nilai Tukar, ROA, DER dan CR Terhadap Return Saham. 85.

Silvaa, G.J. (2014). Basic Interest Rate, Bank Competition and Bank Spread in Personal Credit Operations in Brazil : A Theoseticel and Empirical Analysis. 08.

Anjarwati, Y. T. (2016). Analisis Perubahan Faktor Makroekonomi Terhadap Return On Assets (ROA) Perbankan Persero Di Indonesia Periode 2006Q12015Q4. 33.

Dr.Mamduh M. Hanafi, M. (2004). Manajemen Keuangan. Yogyakarta: BBFE-Yogyakarta.

Drs. Alam S., M. (2006). Ekonomi. Jakarta: Erlangga.

Onny. K. (2015). Pandangan M. Umer Chapra Tentang Upaya Menekan Inflasi Pada Tingkat Sangat Rendah Perspektif Ekonomi Islam. 17.
Mishkin, F. S. (2008). The Economics of Money, Banking, and Financial Markets. Jakarta: Selemba Empat.

Sahara, A. Y. (2013). Analisis Pengaruh Inflasi, Suku Bunga BI, Dan Produk Domestik Bruto Terhadap Return On Asset (ROA) Bank Syariah Di Indonesia. Ilmu Manajeme Volume 1 Nomor $1,155$.

Silvaa, G. J. (2004). Basic interest rate, bank competition and bank spread in personalcredit operations in Brazil: A theoretical and empirical analysis. Journal Economia. Econ-45 ; No.of pages $14,19$.

Suhardi, G. (2013). Usaha Perbankan Dalam Perspektif Hukum. Yogyakarta: KANISIUS (Anggota IKAPI).

Syaichu, E. S. (2013). Analisis Pengaruh Suku Bunga,Inflasi,CAR,BOPO,NPF terhadap ROA Bank Syariah.02.

Tandelilin, Eduardus, " Analisis Investasi dan Manajemen Portofolio", Edisis Pertama, Yogyakarta: BPFE, 2013.

Diana Puspitasari, S. (2009). Analisis Pengaruh CAR, NPL, PDN, NIM, BOPO, LDR, dan Suku Bunga SBI Terhadap ROA. 47.

Supriyanti, N. (2009). Analisis Pengaruh Inflasi dan Suku Bunga BI Terhadap Kinerja Keuangan PT.Bank Mandiri, Tbk Berdasarkan Rasio Keuangan. 19.

Sugiyono. (2013). Metode Penelitian Kuantitatif, Kualitatif R $\& D$. Bandung: Alfabeta. 
Jurnal Ekonomi dan Bisnis Indonesia

JEBI Vol. 04, No.01, pp. 1-8 